\title{
Upaya Peningkatan Kompetensi Guru Ips Dalam Mengembangkan Silabus dan Menyusun RPP Dengan Standar Proses di SMP Negeri Kabupaten Blitar
}

\author{
Mursini ${ }^{(1)}$ \\ ${ }^{1}$ Dinas Pendidikan Kabupaten Blitar \\ Email: ${ }^{1}$ mursini_imam@yahoo.co.id \\ DOI: https://doi.org/10.28926/riset_konseptual.v2i4.85
}

\begin{abstract}
ABSTRAK
Kompetensi sebagai penguasaan terhadap suatu tugas ,ketrampilan, sikap dan aspirasi yang diperlukan untuk menunjang keberhasilan (Mulyasa, 2003:38) penelitian ini berdasarkan permasalahan bagaimanakah peningkatan kompetensi guru mata pelajaran IPS dalam mengembangkan silabus dan RPP sesuai dengan standar proses. Tujuan penelitian ini adalah ingin mengetahui peningkatan kompetensi guru mata pelajaran IPS dalam mengembangkan silabus dan RPP sesuai dengan standar proses .Penelitian ini menggunakan penelitian tindakan (action research) sebanyak 2 siklus, setiap putaran terdiri dari empat tahap yaitu rancangan, kegiatan dan pengamatan ,refleksi da revisi. Sasaran penelitian ini adalah guru mata pelajaran IPS di SMP Negeri Kabupaten Blitar.
\end{abstract}

Kata kunci: kompetensi Guru IPS, mengembangkan silabus, menyusun RPP

\section{PENDAHULUAN}

Pembelajaran dalam tataran idealnya harus direncanakan, dilaksanakan, dan dinilai oleh seorang guru serta diawasi oleh kepala sekolah. Namun, dalam praktiknya di lapangan hal ini yang tidak begitu diperhatikan oleh guru yang harus memiliki kompetensi pedagogik dan kepala sekolah yang harus memiliki kompetensi supervisor.

Dari hasil wawancara dengan kepala sekolah dapat disimpulkan bahwa kegagalan guru untuk membuat peserta didik itu belajar disebabkan karena faktor guru itu sendiri dan pengawasan kepala sekolah terhadap kinerja dari seorang guru yang bersifat instruksi bukan bersifat bimbingan atau bantuan. Sedangkan dari keterangan guru dapat disimpulkan bahwa, guru bingung ketika harus merumuskan RPP karena mata pelajaran yang diajar berbeda dengan latar belakang pendidikannya dan guru biasanya tinggal mengambil atau copy-paste dari MGMP.

Penelitian ini peneliti batasi pada RPP, seorang guru yang kebingungan atau Copy-paste dalam membuat RPP jauh dari RPP sesuai dengan prinsip-prinsip pengembangan KTSP atau menurut Permendiknas No 41 Tahun 2007 akan berdampak pada kegagalan proses pembelajaran dan menghambat pula peningkatan mutu sekolah itu sendiri, sehingga upaya untuk meningkatkan kompetensi guru dalam menyusun RPP menjadi fokus dalam penelitian ini.

Perencanaan merupakan sesuatu yang inti dalam melaksanakan kegiatan termasuk pembelajaran, salah satu komponen yang harus dilakukan seorang guru ketika merencanakan pembelajaran adalah membuat RPP menurut Permendiknas No 41 Tahun 2007 sehingga dapat tercipta pembelajaran yang mengairahkan bagi para peserta didik. Dalam pembuatan RPP menurut Permendiknas No 41 Tahun 2007 ini diperlukan pengawasan dari pengawas pembina. Pengawas sekolah yang selanjutnya dalam penelitian ini disebut sebagai seorang supervisor membina, membimbing, dan memberikan bantuan terhadap guru dalam upaya peningkatan kompetensi guru IPS dalam mengembangkan silabus dan menyusun RPP dengan standar proses di SMP Negeri Kabupaten Blitar.

Peneliti menemukan kesenjangan antara RPP IPS yang dibuat guru dengan RPP menurut Permendiknas No 41 tahun 2007. Kesenjangan atau beberapa komponen yang tidak sesuai dengan Permendiknas No 41 tahun 2007 yaitu, pertama, 
identitas mata pelajaran belum lengkap, dalam RPP IPS tersebut belum mencantumkan satuan pendidikan, kedua, kegiatan pembelajaran yakni dalam kegiatan inti belum mencantumkan proses eksplorasi, elaborasi, dan konfirmasi, ketiga, penilaian hasil belajar belum lengkap, dalam RPP IPS tersebut belum mencantumkan cara penyekorannya. Hal yang sama peneliti juga jumpai pada RPP mata pelajaran lain yang dalam kegiatan pembelajaran terutama dalam kegiatan inti belum mencantumkan proses eksplorasi, elaborasi, dan konfirmasi.

Pengawas sekolah sebagai seorang supervisor akan melakukan supervisi klinis terhadap guru dalam dalam mengembangkan silabus dan menyusun RPP dengan standar proses di SMP Negeri Kabupaten Blitar sehingga dalam pengawasan yang diberikan supervisor ini dapat meningkatkan profesionalitas guru dan meningkatkan pembelajaran melalui pembelajaran efektif sehingga penelitian ini menjadi penting untuk dilakukan karena berupaya meningkatkan kompetensi guru dalam mengembangkan silabus dan menyusun RPP dengan standar proses di SMP Negeri Kabupaten Blitar.

Masalah-masalah pokok dalam penelitian ini adalah (1) Bagaimana kompetensi awal guru dalam mengembangkan silabus dan menyusun RPP, (2) Bagaimana penerapan standar proses untuk meningkatkan kompetensi guru dalam mengembangkan silabus dan menyusun RPP, (3) Bagaimana peningkatan kompetensi guru IPS dalam mengembangkan silabus dan menyusun RPP dengan standar proses di SMP Negeri Kabupaten Blitar.

Penelitian ini bermanfaat untuk meningkatkan kompetensi guru IPS dalam upaya menjabarkan kurikulum atau program pembelajaran sesuai dengan tuntutan dan konteks lokal, sekolah, serta kelas. Hal ini turut memperkuat relevansi pembelajaran bagi kebutuhan peserta didik. Dengan kompetensi menyusun RPP dengan standar proses yang handal diharapkan para guru dapat memenuhi kompetensinya terutama kompetensi pedagogik. Selain itu dari penelitian ini dapat Meningkatkan profesionalisme guru IPS yang berkaitan kompetensinya sebagai seorang agen pembelajaran di sekolah.

Sehubungan dengan uraian-uraian yang peneliti sampaikan diatas maka peneliti telah melakukan penelitian dengan judul "upaya peningkatan kompetensi guru IPS dalam mengembangkan silabus dan menyusun RPP dengan standar proses di SMP Negeri Kabupaten Blitar".

\section{METODE}

Jenis penelitian yang digunakan adalah penelitian yang menggunakan desain Penelitian Tindakan Sekolah (PTS) dengan pendekatan kualitatif. Sugiyono (2009:10) mengemukakan bahwa penelitian kualitatif memandang objek sebagai sesuatu yang dinamis, hasil konstruksi pemikiran, dan interpretasi terhadap gejala yang diamati, serta utuh (holistik) karena setiap aspek dari objek itu mempunyai satu kesatuan yang tidak dapat dipisahkan, jadi realitas itu merupakan konstruksi atau interpretasi dari pemahaman terhadap semua data yang tampak di lapangan.

Penelitian ini merupakan suatu rangkaian langkah untuk mengatasi permasalahan yang timbul dalam ruang lingkup sekolah. Mulyasa (2009:9) mengemukakan bahwa penelitian tindakan sekolah (PTS) merupakan upaya untuk meningkatkan kinerja sistem pendidikan dan mengembangkan manajemen sekolah agar menjadi lebih produktif, efektif, dan efisien. PTS dapat diartikan sebagai sebuah upaya untuk memperbaiki kondisi dan memecahkan berbagai persoalan pendidikan yang dihadapi di sekolah. Pengertian tersebut menunjuk pada dua kata yang satu diantaranya harus ada dalam kegiatan penelitian tindakan sekolah, yaitu pemecahan masalah (problem solving) dan peningkatan (improving) kinerja sistem pendidikan serta manajemen sekolah, yang secara keseluruhan akan berdampak pada peningkatan mutu. Lebih lanjut Aqib (2009:3) juga mengungkapkan bahwa hakikat dari kegiatan PTS adalah seorang kepala sekolah atau pengawas yang memperbaiki kualitas penyelenggaraan pendidikan. 
Vol. 2 No. 4, Oktober 2018;

Subjek penelitian dalam penelitian ini adalah guru IPS dari sekolah binaan di Kabupaten Blitar . jumlah subjek penelitian ini 40 guru IPS. Penelitian ini dilaksanakan Sejak bulan juli 2014 hingga oktober 2014 sehingga dapat dikatakan waktu penelitian ini pada tahun pelajaran 2014/2015.

Penelitian ini difokuskan pada kompetensi awal guru dalam mengembangkan silabus dan menyusun RPP menurut Permendiknas No 41 Tahun 2007, penerapan supervisi klinis dalam meningkatkan kompetensi guru dalam menyusun RPP menurut Permendiknas No 41 Tahun 2007, dan peningkatan kompetensi guru dalam menyusun RPP menurut Permendiknas No 41 Tahun 2007. Dalam penelitian ini tidak melihat aspek lain selain standar proses yang membuat peningkatan kompetensi guru IPS dalam mengembangkan silabus dan menyusun RPP.

Instrumen penelitian merupakan alat bantu dalam mengumpulkan data. Dalam penelitian ini yang berorientasi pada proses membuat peneliti berfokus pada proses tindakan yang meliputi perilaku supervisor dan guru, respon dari guru mengenai supervisor dan tindakan yang diberikan, dan suasana proses tindakan sehingga penelitilah yang menjadi instrumen kunci dengan bantuan lembar observasi dan pedoman wawancara. Selain itu untuk menilai kompetensi guru dalam menyusun RPP supervisor memberikan penilaian berpedoman pada APKG (Acuan Penilaian Kompetensi Guru) kemudian supervisor memberikan umpan balik dengan berpedoman pada hasil penilaian menurut APKG dan berdasarkan komponen serta prinsip penyusunan RPP menurut Permendiknas No 41 Tahun 2007, umpan balik dari pengawas sekolah/supervisor ini berguna untuk mengetahui kekurangan dari RPP yang dibuat guru. Catatan lapangan dari dokumentasi (Hasil penilaian \& umpan balik pengawas sekolah/supervisor) dipakai untuk mendeskripsikan kondisi awal kompetensi guru dalam mengembangkan silabus dan menyusun RPP dan peningkatan kompetensi guru IPS dalam mengembangkan silabus dan menyusun RPP, sedangkan catatan lapangan dari observasi, wawancara, dan dokumentasi (foto) digunakan untuk mendeskripsikan penerapan tindakan yang dilakukan meliputi bagaimana perilaku supervisor, perilaku subjek penelitian, dan suasana yang terjadi saat itu terhadap pembelajaran IPS.

Teknik analisis data yang digunakan dalam penelitian ini adalah naratif kualitatif yakni mendeskripsikan atau menggambarkan bagaimana kondisi awal kompetensi guru dalam menyusun RPP, pelaksanaan tindakan memberikan supervisi pada guru untuk menyusun RPP yang sesuai dengan Permendiknas No 41, dan peningkatan yang dialami guru dalam menyusun RPP. Miles \& Huberman (Dalam Sugiyono, 2009:246) mengemukakan bahwa aktivitas dalam analisis data kualitatif dilakukan secara interaktif dan berlangsung secara terus sampai tuntas, sehingga datanya sudah jenuh. Aktivitas dalam analisis data, yaitu reduksi data, penyajian data, dan penarikan kesimpulan.

Penelitian ini menggunakan penelitian tindakan (action research) sebanyak 2 siklus, setiap putaran terdiri dari empat tahap yaitu rancangan, kegiatan dan pengamatan ,refleksi da revisi . Sasaran penelitian ini adalah guru mata pelajaran IPS di SMP Negeri Kabupaten Blitar Dari hasil analisis didapatkan bahwa kompetensi guru mata pelajaran IPS dalam menyusun silabus dan RPP sesuai mengalami peningkatan dari siklus I (mengembangkan silabus 30\% dan menyusun RPP $30 \%$ ), menjadi pada siklus II (mengembangkan silabus 80\% dan menyusun RPP 80\%) Sedangkan dari hasil penelitian menunjukkan bahwa kompetensi guru dalam mengembangkan silabus dan RPP sesuai standar proses mengalami peningkatan sehingga berpengaruh terhadap pembelajaran di kelas .Kesimpulan dari penelitian ini adalah dengan kompetensi guru mata pelajaran IPS dalam mengembangkan silabus dan menyusun RPP sesuai dengan standar proses dapat berpengaruh positif terhadap pembelajaran siswa di SMP Negeri Kabupaten Blitar sehingga dapat digunakan sebagai pembelajaran bidang studi yang lain.

Penelitian ini terbagi menjadi dua siklus yakni siklus I \& siklus II. Kegiatan siklus I ini berguna untuk mengetahui kompetensi awal guru dalam mengembangkan 
dan menyusun RPP menurut Permendiknas No 41 Tahun 2007. Dari hasil penilaian dan umpan balik yang telah diberikan supervisor dapat disimpulkan bahwa terdapat kesenjangan antara RPP yang dibuat guru dan RPP menurut Permendiknas No 41 Tahun 2007 terutama dalam perumusan langkah kegiatan inti yang belum menampilkan proses eksplorasi, elaborasi, serta konfirmasi dan instrumen penilaian yang belum lengkap. Siklus I terdiri perencanaan, pelaksanaan, observasi, dan refleksi. Dalam kegiatan perencanaan tindakan supervisor membuat kesepakatan waktu dan tempat bersama subjek penelitian untuk berdiskusi tentang mengembangkan silabus, RPP yang telah dibuatnya, menyiapkan rencana pelaksanaan pertemuan, menyiapkan materi yang akan disampaikan, menyiapkan lembar observasi kegiatan, dan menyiapkan pedoman wawancara.

Dalam pelaksanaan tindakan, pada hari sabtu tanggal 20 November 2014, subjek penelitian bersepakat untuk berdiskusi tentang RPP yang ideal seperti apa. Pertemuan ini disepakati dimulai pada jam 10.00 di aula sekolah binaan Kabupaten Blitar. Dalam observasi tindakan yang dilakukan peneliti berlangsung setelah kegiatan untuk memberikan penilaian terhadap RPP yang dibuat guru dengan berpedoman pada APKG dan memberi umpan balik berdasarkan hasil penilaian serta berdasarkan komponen \& prinsip penyusunan RPP menurut Permendiknas No 41 Tahun 2007. Dari hasil penilaian terhadap RPP yang dibuat guru dapat disimpulkan bahwa RPP yang dibuat sudah sesuai dengan Permendiknas tetapi ada beberapa komponen yang harus dilengkapi seperti dalam kegiatan inti belum mencantumkan kegiatan eksplorasi, elaborasi, dan konfirmasi dan instrumen penilaiannya belum lengkap dan dari hasil penilaian tersebut supervisor memberikan umpan balik terhadap guru. Dalam kegiatan refleksi, terdapat beberapa kekurangan dalam pelaksanaan tindakan yakni diperlukannya seorang ahli desain pembelajaran untuk memberikan penguatan dalam guru menyusun RPP sehingga dalam kegiatan atau siklus berikutnya dapat diajak untuk berkolaborasi sedangkan kelebihan dari tindakan ini terjadi peningkatan kompetensi guru dalam menyusun RPP terutama yang berkenaan dengan kegiatan inti dan instrumen penilaian. Subjek penelitian merasa mendapat tambahan pengetahuan tentang penyusunan RPP sesuai Permendiknas No 41 Tahun 2007, supervisor menilai kompetensi subjek penelitian dalam menentukan metode pembelajaran yang tepat sesuai dengan situasi dan kondisi siswa masih perlu untuk ditingkatkan, dan supervisor selain memberikan umpan balik secara tertulis perlu kiranya memberikan umpan balik secara lisan.

Siklus II terdiri perencanaan, pelaksanaan, observasi, dan refleksi. Pada kegiatan perencanaan ini beberapa hal yang dilakukan supervisor adalah sebagai berikut: (1) mendorong guru untuk mengemukakan permasalahan yang dialaminya dalam menyusun RPP yakni permasalahan pemilihan metode pembelajaran kemudian membuat solusi bersama subjek penelitian; (2) memberikan umpan balik secara lisan untuk member penguatan terhadap solusi dari masalah subjek penelitian (3) membuat kesepakatan waktu dan tempat bersama subjek penelitian untuk berdiskusi tentang RPP yang telah dibuatnya pada hari sabtu tanggal 19 Oktober 2014 jam 12.30 WIB; dan (4) praktik subjek penelitian dalam menyusun RPP dikerjakan secara mandiri di rumah. Pada hari sabtu tanggal 19 Oktober 2014, pengawas pembina bersama subjek penelitian bersepakat untuk berdialog tentang permasalahan yang dialami subjek penelitian saat mengembangkan silabus dan menyusun RPP dengan standar proses , solusi dari permasalahan tersebut, dan pemberian umpan balik secara lisan oleh pengawas pembina. Pertemuan ini disepakati dimulai sekitar jam 12.30 WIB dan ada seorang subjek penelitian yang tidak hadir yakni MGMP. Pertemuan yang bertempat di ruang multimedia dimulai dengan pengarahan dari pengawas pembina sebagai seorang supervisor untuk membentuk tempat duduk secara melingkar sehingga diskusinya dapat didengar dalam forum. Supervisor kemudian memberikan kesempatan bagi subjek penelitian untuk mengemukakan permasalahan yang dialami saat mengembangkan silabus dan menyusun RPP dengan standar proses untuk dicari solusinya dalam forum MGMP. 
Pada tahap observasi dapat disimpulkan bahwa supervisor pada siklus II terhadap RPP subjek penelitian dapat disimpulkan bahwa kompetensi guru dalam mengembangkan silabus dan menyusun RPP tergolong tinggi karena subjek penelitian dapat memilih metode yang tepat sesuai situasi dan kondisi siswa dan kelas, mencantumkan proses eksplorasi, elaborasi, dan konfirmasi, dan melengkapi instrumen dan dari hasil penilaian tersebut supervisor memberikan umpan balik terhadap guru.

Tahap refleksi dilakukan untuk menentukan apakah tindakan siklus II sudah berhasil atau belum. Berdasarkan analisis hasil penilaian RPP yang dibuat subjek penelitian setelah siklus II berakhir menunjukkan taraf peningkatan dalam menentukan metode yang tepat sesuai dengan situasi dan kondisi siswa dan kelas, mencantumkan proses eksplorasi, elaborasi, dan konfirmasi pada kegiatan inti pembelajaran, dan melengkapi instrumen penilaian. Pada siklus II subjek penelitian telah mengungkapkan permasalahan yang dialaminya saat menyusun RPP dan berdialog bersama supervisor tentang solusi dari permasalahan tersebut. Apabila beberapa orang subjek penelitian masih menemui permasalahan dalam menyusun RPP maka akan diberi masukan atau saran mengenai permasalahan tersebut secara mandiri atau bersifat konsultatif.

Pengawas pembina yang dilakukan terhadap RPP, ternyata mendapat respon dari guru Mapel IPS, guru tersebut mencoba untuk mengimplementasikan dalam pembelajaran dan menularkannya pada guru IPS lain. Dari wawancara yang dilakukan pada ketiga guru IPS dapat disimpulkan bahwa guru IPS yang diberi arahan dan bimbingan dari pengawas pembina mencoba untuk mengaplikasikan RPP dalam pelaksanaan pembelajaran dengan menitikberatkan pada siswa yang belajar serta memakai metode yang inovatif, guru IPS yang diberi tindakan memberikan informasi pada guru IPS lain jika guru lain tersebut bertanya, dan guru IPS yang lain sering mempertanyakan bagaimana menentukan metode yang cocok dalam pembelajaran.

\section{HASIL}

Dari hasil analisis didapatkan bahwa kompetensi guru mata pelajaran IPS dalam menyusun silabus dan RPP sesuai mengalami peningkatan dari siklus I (mengembangkan silabus $30 \%$ dan menyusun RPP $30 \%$ ), menjadi pada siklus II (mengembangkan silabus $80 \%$ dan menyusun RPP $80 \%$ ) Sedangkan dari hasil penelitian menunjukkan bahwa kompetensi guru dalam mengembangkan silabus dan RPP sesuai standar proses mengalami peningkatan sehingga berpengaruh terhadap pembelajaran di kelas.

Kompetensi awal guru dalam mengembangkan silabus menyusun RPP diperoleh dari hasil wawancara dan observasi peneliti terhadap RPP subjek penelitian serta penilaian dan umpan balik dari Supervisor terhadap RPP subjek penelitian saat praobservasi.

Hasil wawancara peneliti terhadap beberapa subjek penelitiandan dapat disimpulkan bahwa guru bingung ketika harus merumuskan RPP karena mata pelajaran yang diajar berbeda dengan latar belakang pendidikannya serta masih menggunakan RPP hasil MGMP yang dirasa belum sesuai dengan Permendiknas No 41 Tahun 2007.

Pada tahap observasi ini supervisor memberikan penilaian terhadap RPP yang dibuat subjek penelitian pada prasiklus, siklus I, dan Siklus II berdasarkan APKG (Alat Penilaian Kompetensi Guru). APKG digunakan sebagai pedoman penilaian RPP dalam penelitian ini karena dalam APKG terdapat berbagai model instrumen yang dapat dipakai dalam penilaian kinerja guru yakni skala penilaian dan (lembar) observasi (Depdiknas, 2008:35). Pada prasiklus supervisor memberikan penilaian terhadap 11 RPP guru yang bersedia menjadi subjek penelitian tetapi pada siklus I \& II supervisor memberikan penilaian terhadap 10 RPP yang dibuat subjek setelah diberi umpan balik karena seorang subjek penelitian tidak mengumpulkan RPP setelah diberi tindakan dengan alasan sibuk karena memliki banyak tugas dari sekolah. 
Vol. 2 No. 4, Oktober 2018;

\section{PEMBAHASAN}

Perbedaan latar belakang pendidikan dengan pelajaran yang diajarkan oleh seorang guru tentu menimbulkan permasalahan dalam pembelajaran. Permasalahannya antara lain guru tersebut tidak memahami konsep-konsep kunci dari sebuah mata pelajaran, guru tersebut kesulitan dalam mengimplementasikan kurikulum suatu mata pelajaran pada pembelajaran terutama pada perencanaan pembelajaran yang bermuara pada RPP, dan tidak terlalu menguasai materi pelajarannya.

Hasil observasi peneliti terhadap RPP mata pelajaran IPS dapat disimpulkan bahwa terdapat kesenjangan antara RPP IPS yang dibuat guru dengan RPP menurut Permendiknas No 41 tahun 2007. Kesenjangan atau beberapa komponen yang tidak sesuai dengan Permendiknas No 41 tahun 2007 yaitu, pertama, identitas mata pelajaran belum lengkap, dalam RPP IPS tersebut belum mencantumkan satuan pendidikan, kedua, kegiatan pembelajaran yakni dalam kegiatan inti belum mencantumkan proses eksplorasi, elaborasi, dan konfirmasi, ketiga, penilaian hasil belajar belum lengkap, dalam RPP IPS tersebut belum mencantumkan cara penyekorannya. Hal yang sama peneliti juga jumpai pada RPP mata pelajaran lain yang dalam kegiatan pembelajaran terutama dalam kegiatan inti belum mencantumkan proses eksplorasi, elaborasi, dan konfirmasi.

Ketidaksesuaian RPP buatan guru didukung oleh hasil penilaian dan umpan balik dari supervisor pada praobservasi terhadap RPP IPS dapat disimpulkan bahwa kompetensi guru IPS dalam menyusun RPP tergolong sedang karena belum mencantumkan proses eksplorasi, elaborasi, dan konfirmasi pada kegiatan inti serta instrumen penilaian belum lengkap sedangkan pada RPP mata pelajaran lain juga ditemukan kesenjangan serupa.

Kompetensi awal guru IPS dalam menyusun RPP jika dilihat dari model analisis kategori dari segi kompetensi atau berpikir abstrak, tergolong rendah karena tidak memiliki inisiatif dalam menyusun RPP karena hanya copy-paste dari MGMP sedangkan kompetensi awal guru mata pelajaran lain dalam menyusun RPP jika dilihat dari model analisis kategori dari segi kompetensi atau berpikir abstrak, tergolong rendah karena guru kebingungan dalam merumuskan RPP karena mata pelajaran yang diajarkan berbeda dengan latar belakang pendidikannya dan tidak memiliki inisiatif dalam menyusun RPP karena hanya copy-paste dari MGMP.

Kompetensi berpikir abstrak yang rendah ini akan mengakibatkan kinerja guru yang belum maksimal terutama dalam pembelajaran di kelas karena pelaksanaan pembelajaran tidak akan maksimal jika tidak didukung oleh perencanaan pembelajaran yang matang dan perencanaan pembelajaran ini bermuara pada RPP. Pembelajaran yang tidak maksimal merupakan permasalahan dalam satuan pendidikan. Kepala sekolah merupakan pimpinan satuan pendidikan yang bertanggung jawab dalam berjalannya pembelajaran, jika pembelajaran tidak maksimal diperlukan supervisi dari kepala sekolah sebagai seorang supervisor untuk menanggulangi masalah guru dalam menyusun RPP.

Pada tahap pendahuluan, supervisor melakukan kesepakatan dengan subjek penelitian tentang waktu dan tempat supervisi serta pemberian informasi tentang tujuan pelaksanaan supervisi. Kemudian supervisor pada saat pelaksanaan supervisi klinis pada siklus I memberikan informasi yang berkaitan dengan RPP dan pada siklus II bersama subjek penelitian menggali permasalahan yang dialami subjek saat menyusun RPP serta dicari solusinya bersama supervisor.

Hal diatas sesuai dengan pendapat dari Burhanuddin, dkk (2007:37) bahwa pada pertemuan pendahuluan atau praobservasi, supervisor membicarakan kompetensi mengajar yang ingin ditingkatkan oleh guru kemudian disepakati bersama oleh guru dan supervisor. Pelaksanaan supervisi klinis pada tahap pendahuluan ini membutuhkan kiat supervisor dalam menciptakan suasana yang menyenangkan, suasana kekeluargaan, kesejawatan, dan kehangatan. Guru tidak merasa takut atau 
tertekan sehingga guru mau dan berani mengungkapkan permasalahan dan kebutuhan dalam mengajar di kelas.

\section{KESIMPULAN}

Hasil penelitian dan pembahasan menunjukkan bahwa (1) kompetensi awal guru dalam menyusun RPP tergolong rendah karena guru kebingungan dalam merumuskan RPP karena mata pelajaran yang diajarkan berbeda dengan latar belakang yang dimiliki dan tidak memiliki inisiatif dalam menyusun RPP karena hanya copy-paste dari MGMP; (2) penerapan supervisi klinis untuk meningkatkan kompetensi guru dalam menyusun RPP terbagi menjadi dua siklus dalam setiap siklus melalui tiga tahap yakni tahap pendahuluan, observasi, dan umpan balik. Penerapan supervisi klinis ini dapat dikatakan berhasil karena ketiga tahap dalam setiap siklus berjalan lancar; (3) penerapan supervisi klinis dapat meningkatkan kompetensi guru dalam menyusun RPP. Hal ini dapat dilihat dari perubahan ke arah yang lebih baik dari subjek penelitian dalam menyusun RPP. Pada prasiklus kompetensi guru dalam menyusun RPP tergolong rendah karena guru kebingungan dalam merumuskan RPP karena mata pelajaran yang diajarkan berbeda dengan latar belakang yang dimiliki dan tidak memiliki inisiatif dalam menyusun RPP karena hanya copy-paste dari MGMP. Pada siklus I kompetensi guru dalam menyusun RPP tergolong sedang karena subjek penelitian kebingungan dalam memilih metode pembelajaran yang tepat dan pada RPP dalam langkah-langkah pembelajaran belum menekankan pada kegiatan siswa untuk belajar. Pada siklus II kompetensi guru dalam menyusun RPP tergolong tinggi karena dapat memperbaiki kekurangan RPP sesuai dengan umpan balik supervisor yakni telah mencantumkan proses eksplorasi, elaborasi, dan konfirmasi pada kegiatan inti, mencantumkan instrumen secara lengkap, serta menentukan metode dengan tepat dan dapat memecahkan masalah dalam menyusun RPP dengan berbagai alternatif solusi; dan (4) implikasi pelaksanaan pada pembelajaran IPS, guru mulai menerapkan pembelajaran inovatif bukan hanya bertumpu pada ceramah tetapi juga siswa mulai dikembangkan untuk mengkonstruksikan pengetahuannya sendiri. Dari hasil analisis data didapatkan bukti bahwa kompetensi guru dalam menyusun RPP mengalami peningkatan secara signifikan.

\section{SARAN}

Sebaiknuya guru melakukan penerapan supervisi klinis untuk meningkatkan kompetensi guru dalam menyusun RPP terbagi menjadi dua siklus dalam setiap siklus yang melalui tiga tahap yakni tahap pendahuluan, observasi, dan umpan balik.

\section{DAFTAR RUJUKAN}

Aqib, Z. 2009. Penelitian Tindakan Sekolah. Bandung: CV Yrama Widya

Burhanuddin., dkk. 2007. Supervisi Pendidikan Dan Pengajaran: Konsep, Pendekatan, dan Penerapan Pembinaan Profesional. Malang: FIP UM

Maisyaroh. 2001. Supervisi Klinis: Salah Satu Pendekatan Dalam Pelaksanaan Supervisi Pengajaran. Malang: FIP UM.

Mulyasa, E. 2009. Penelitian Tindakan Sekolah. Bandung: PT Remaja Rosdakarya

Muslim, SB. 2009. Supervisi Pendidikan Meningkatkan Kualitas Profesionalisme Guru. Bandung: CV Alfabeta. 